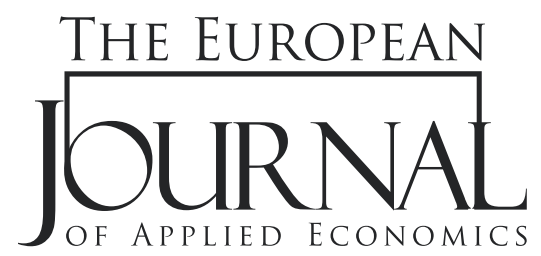

EJAE 2019, 16(1): 77-98

ISSN 2406-2588

UDK: 005.334:009.96

338.124.4(596.2)

DOI: 10.5937/EJAE15-19262

Original paper/Originalni naučni rad

\title{
RESULTANT EFFECT OF CRISIS-DRIVEN HR STRATEGIES APPLIED DURING CURRENT ECONOMIC CRISIS IN OMAN - AN HR MANAGER'S PERSPECTIVE
}

\author{
Venkat Ram Raj Thumiki ${ }^{1}$, Ana Jovancai Stakić ${ }^{1, *}$, Rayaan Said Sulaiman Al Barwani ${ }^{2}$ \\ ${ }^{1}$ Modern College of Business and Science, \\ Muscat, Sultanate of Oman \\ ${ }^{2}$ Franklin University, \\ Columbus, Ohio
}

\begin{abstract}
:
During an economic crisis, companies redesign their functional strategies for survival and growth. This paper aims at identifying HR practices adopted during the current economic crisis in Oman, and explains the resultant effect of crisis-driven HR strategies from an HR managers' perspective. Primary data was collected online from $112 \mathrm{HR}$ managers representing various manufacturing and service organizations in Muscat, Oman. It was found that HR managers perceive a greater impact of economic crisis on their businesses rather than other types of crises such as natural and technology crises. They think that managing employees during an economic crisis is relatively easier than managing other resources and other stakeholders. Changing HR practices during economic crises include, abeyance of employee benefits and cutting costs on employee recreation. Knowledge management activities have been increased and non-monetary motivation techniques are being adopted as a part of crisis-driven HR management. Increased employee engagement and enhanced corporate image among employees were identified as the resultant effect. Testing the hypothesis revealed that cost cutting on employee recreation is significantly higher in large organizations, job redesign activity is significantly higher in small organizations, while large organizations find it difficult to deal with employees during periods of crisis more so than small and medium sized organizations do.
\end{abstract}

\section{Article info:}

Received: October 23, 2018

Correction: December 5, 2018

Accepted: April 8, 2019

\section{Keywords:}

economic crisis,

abeyance,

job redesign,

non-monetary motivation, knowledge management. 


\section{INTRODUCTION}

In the business world, where crisis is common, how an organization acts and responds to the crisis and how it motivates its employees (Silverthorne, 2018) speaks about how successfully it will survive (Argenti, 2002). Crisis management is a process that includes, understanding crises before they occurs, preventing crisis situations whenever possible, managing business functions during crises and handling post-crisis situations (Augustine, 1995). There are various types of crises, such as natural crises, technological crises, economic crises, crises of malevolence, etc. (Hart et al., 1993). Cyclone Gonu created a natural crisis in Oman in 2007 that resulted in a temporary shut-down of the Sohar and Qaboos ports and lowering operational level of oil refinery petrochemical plant in Sohar (Fritz et al., 2010). Emma Storm caused disruption to the supplies and affected the retail industry in England (Woods, 2018). A malevolence crisis was recorded in Sony Picture Entertainment in 2014, due to a cyberattack that leaked information regarding the release of its upcoming films (Peterson, 2014). Another example of a malevolence crisis is the 'Ransomware' attack committed by a hacker using the 'WannaCry' malware (Graham, 2017). Along with macro environmental factors, such as oil price fluctuations, internal factors such as organizational misdeeds, mismanagement and mishandling of situations could also cause crisis in a company (Coombs \& Holladay, 2002). An important aspect to note is that, whatever the type of crisis may be, the impact will be on one of the key stakeholders, i.e., employees (Coombs, 2004) and lack of knowledge of HR policies among employees could lead to aggravating the situation (Narayanan et al., 2018).

Current research addresses the role of HRM in times of economic crisis through capturing the crisis-driven HR strategies and further understanding the resultant effect of those strategies on human resources from the HR managers' perspective.

The current economic crisis in Oman started in 2014 with the reduction in oil prices (Elrich, 2015) as Oman depends on oil for more than two thirds of its budget ( $i b i d$ ). This lowered the investments in the oil sector and reduced the spending by the Government (The National, 5 March, 2015) which resulted in decelerating economic growth in the Sultanate in 2016 (fanack.com, 21 Feb, 2018). Though the available literature indicates betterment of the economic situation (Focus economics, 10 April, 2018), forecasts and experts' opinions indicate that the Omani economy has not yet entered into a post-crisis situation (Focus Economics,) and is still in an economic crisis (Times of Oman, 10 January, 2018).

\section{LITERATURE REVIEW}

According to a research by Fink (1986) which was further emphasized by Bergstrom (2018), among organizations that have not planned for a crisis and are unprepared for potential crises, the crisis lasted two-and-a-half times longer than those companies that did have a plan in place. Spillan and Hough (2003), who conducted a study in Pennsylvania and New York found that $15 \%$ of companies had crisis management teams. An important finding from their study, which is relevant to Oman, is that the small business owners showed a slight apprehension towards crises which could lead to unpreparedness. The following sections present the reviewed literature relating to economic crises, and the role of HRM and HRM strategies pre, during, and post crisis.

As HRM is one of the most crucial functions that affect the organizational efficiency (Noe et al., 2011; Ochetan \& Ochetan, 2012) and employment relations (Kirov \& Thill, 2018), it is important to emphasize its role in crisis management (Barton, 2000; Luxford, 2008). Functional managers need to devise crisis-specific strategies in their respective functions in which the HR department's involvement is imperative (Fodor \& Poor, 2009). During a crisis, as employees may not voice their opinion (Prouska \& Psychogios, 2016), the role of the HR department becomes crucial (Wooten \& James, 2008) because 
this department is in-charge of handling employee affairs, formulating rules and regulations, employee training and development, etc. (Burma, 2014). Some of the commonly applied HR strategies during a crisis include, downsizing, cost cutting, postponing benefits, etc. (Howard, 2013; HRMA, 2014), which could influence employee perception towards work (Coombs, 2007).

Pre-crisis HR strategies: The HR department needs to be environmentaly sensitive (Vardarlier, 2016) and may have to identify a crisis before it occurs because it will certainly affect their human resources (Baubion, 2013). After estimating and defining the potential crisis, the HR manager needs to devise appropriate crisis response plans, crisis communication plans, crisis management teams; the manager may have to revisit HR policies and strategies (Workplace Info Writers, 2006). The HR department in association with various functional heads must engage its personnel in multiple operational training programs that enable them to prepare for the potential crisis from all dimensions (Coombs, 2007).

HR strategies during crisis: According to Hendry and Pettigrew (1986), companies can survive a crisis through effective management of human resources. In-crisis HRM strategies include, redesigning organization structure, providing necessary knowledge and training to employees regarding performing during crisis, etc. (Ochetan \& Ochetan, 2012). HR departments need to ensure their employees wellbeing, job security, and enhance the value of human capital as a part of in-crisis HR strategy (HRMA, 2014; Howard, 2013). Crisis communication plays an important role, as it requires expertise and special skill (Coombs \& Holladay, 1996). The HR department is the contact-point between a company and its employees (Burma, 2014). The first step towards crisis communication with employees during a crisis is to communicate with the right people in the team about the situation so that they can handle the relevant issues (Coombs \& Holladay, 1996). Employees of HR departments who speak on behalf of the company need to be trained in crisis communication (Fener \& Cevik, 2015) so that they can effectively communicate with the external stakeholders during a crisis. Crises influence organizations' outlooks on managing situations during a crisis (Argenti, 2002), and the result is that the companies started building crisis management teams (Kondrasuk, 2004).

Post-crisis HR strategies: By being environmentally sensitive, the HR managers need to identify the end of the crisis, and may have to plan for expansion and growth strategies. Post-crisis HR strategies include, recovery plans, increased recruitment of manpower, redesigning the organizational structure, etc. (Matsuka, 2010), along with effective supervisor support that could positively influence the employees' perception of the the organization (Straub et al., 2018).

\section{RESEARCH METHODOLOGY}

Primary Data-Questionnaire design: Primary data was collected through administering an online questionnaire created using Google Forms. It contained a question on the number of employees along with a question on the sector in which the organization was operating. Questions were aimed at capturing the awareness level of HR managers of the current economic crisis, their perception of impact of economic crisis on human resources of the organization, their HR practices during the current economic crisis, along with the problems that they had been encountering as a result of crisis-driven HR strategies. A monadic rating scale (Smith \& Albaum, 2010) was used to understand HR managers' rating of difficulty level of dealing with various resources during crises along with identifying their perception of the resultant effect of their crisis-driven HR strategies. A semantic differential scale was used to identify HR managers' level of implementation of various HR strategies during the current crisis (Saunders et al., 2007). ${ }^{1}$

1 The dataset is publicly available via following web link: https://data.mendeley.com/datasets/bdbntgy6fc/draft?a=cb2e3e9b516b-4189-9894-8095fb00f9f0 
Reliability and Validity of the Questionnaire: The instrument used to collect primary data from HR managers was tested (Kothari, 2004) using two methods, firstly, the test of face validity (Saunders et al., 2007) where in an expert has reviewed the questionnaire, and suggested changes and secondly, through calculating Cronbach's Alpha (Cronbach, 1951), which is presented in the reliability section.

Sample Plan: An online questionnaire was distributed to more than 250 respondents using snowball sampling technique (Smith \& Albaum, 2010) in which the respondents (HR managers in this case) were requested to send the questionnaire to their contacts. However, due to a low response rate (Nulty, 2008), only 116 valid responses were received out of which 112 responses were used in data analysis. Four responses were excluded from the analysis, as they are identified as a 'non-representative' sample.

Reason for Excluding Four Responses: On the questionnaire, the item measuring HR Managers' perception of impact of different types of crises on their business as 'Not applicable' as one of its options. Out of a total of seven types of crises presented, one or few of the crises may not be applicable to some types of businesses. Hence, the 'Non-applicable' option was included. Out of the 116 responses received, four respondents indicated that all seven types of crises were not applicable to them. Thus, they become a non-representative sample. The reason could be either their businesses or the organizations are not impacted by the crisis, or that they did not understand the question. In both cases, the responses do not fall under the scope of the research. Hence, are not included in the analysis.

Statistical Analysis: The research output of the current research is explained through quantitative analyses using frequency distribution and percentages. Descriptive statistics, including mean, median, and standard deviation are used to describe the nature of the findings. Hypotheses were tested using ANOVA to find the differences between multiple groups and a T-test to find the differences between two groups of respondents.

Secondary Data: Various sources of secondary data that are used for this study include, websites of companies and newspapers (Times of Oman, Oman Observer, The National). As part of secondary data information regarding HR strategies during crises was collected from published journal articles and reports by experts (Saunders et al., 2007).

Data Analysis Software: Data analysis software, SPSS (17.0) was used to analyse the collected data using all relevant statistical tools and techniques (Field, 2012).

\section{RESULTS AND DISCUSSION}

The following section focuses on analyzing the data collected from 112 respondents who are HR managers in various organizations in Muscat. It provides the findings related to HR practices during the current economic crisis and the HR managers' perception of the resultant effect of their crisisdriven HR strategies.

\section{Sample Characteristics}

Nearly half (49.1\%) of the respondents represented organizations with an employee-size of 101 to 500 . The majority of the respondents (72\%) were from the service sector representing, telecomunications, airlines, construction, banking, insurance, retail, education and health sectors. Due to the increase in non-oil diversification strategy in Oman (Times of Oman, 7 Feb, 2018), more jobs are now created in the service sector (Oman Observer, $25 \mathrm{Feb}, 2018$ ). The sample, therefore, becomes valid for the study.

\section{HR Managers' Perception of the 'impact of different types of crises on their businesses'}

Seven types of crises were presented to the respondents viz., 1) natural crisis: floods, 2) economic crisis: economic downturn, 3) technological crisis: computer malware attack, 4) malevolence crisis: extreme tactics by miscreant individuals, 5) deception crisis: deliberate wrong actions taken by 
management, 6) workplace violence: strikes or other related problems, and 7) rumors: about the company or its products spread in society. Respondents were asked to rate the impact of each type of crisis on their businesses. The measurement scale ranged from 1 to 5,1 being no impact at all and 5 having significantly high impact with an additional 'not applicable' option. While calculating averages, 'not applicable' responses were not considered as they were not included in the 'population of interest' (Smith \& Albaum, 2010).

\begin{tabular}{lcccc}
\hline & N & $\begin{array}{c}\text { Not } \\
\text { applicable }\end{array}$ & $\begin{array}{c}\text { Average rating } \\
\text { (scale 1-5) }\end{array}$ & $\begin{array}{c}\text { Std. } \\
\text { Dev. }\end{array}$ \\
\hline Perceived impact of natural crisis on business & 104 & 8 & 2.90 & 1.383 \\
\hline Perceived impact of economic crisis on business & 108 & 4 & 3.53 & 1.080 \\
\hline Perceived impact of technology crisis on business & 108 & 4 & 3.37 & 1.173 \\
\hline Perceived impact of malevolence crisis on business & 91 & 21 & 3.01 & 1.378 \\
\hline Perceived impact of deception crisis on business & 89 & 23 & 3.20 & 1.208 \\
\hline Perceived impact of workplace violence crisis on business & 81 & 31 & 3.00 & 1.423 \\
\hline Perceived impact of rumors based crisis on business & 88 & 24 & 3.00 & 1.232 \\
\hline
\end{tabular}

Table 1. HR Managers' Perception of Impact of Different Types of Crises on their Businesses

Findings related to HR managers' perception of impact of different types of crises on their respective businesses can be seen in Table 1. It was found that HR managers perceived greater impact of economic crisis (3.53) and technology crisis (3.37) over other crises on their businesses. The low standard deviation (1.080) indicates closeness of the opinions. This finding empirically proves the importance given to economic crisis by the companies. Furthermore, as presented in Table 2, more than $97 \%$ of the respondents were knowledgeable about the current economic crisis.

\begin{tabular}{lccc}
\hline & Frequency & Percent \\
\hline Unknown to me & 0 & $0 \%$ & \\
\hline I know a little from others & 3 & $2.7 \%$ & \multirow{2}{*}{$97.3 \%$} \\
\hline I read about it a number of times & 37 & $47.3 \%$ & \\
\hline I read about it regularly & 53 & $17 \%$ & \\
\hline I have extensive knowledge about it & 19 & $100 \%$ \\
\hline Total & 112 & \\
\hline
\end{tabular}

Table 2. Level of Awareness of Current Economic Crisis

\section{Impact of Current Economic Crisis on the Organization}

The majority of the respondents (80.4\%) specified that the current economic crisis had an impact on their organization which can be interpreted as 'it affected their HR strategies'. Though a similar finding is presented in Table 1, it addresses the impact of the economic crisis in general whereas this finding is specific to the current economic crisis and also with reference to HR function. These two questions validate the findings and can be treated as evidence of validity and reliability of the questionnaire. 
Possible ways of the impact of the economic crisis on HR could be downsizing, reducing costs, hiring of trainees or contractors to pay less wages, suspending promotions and extra privileges, changing HR policies, rules and regulations, etc.

\section{Difficulty in Dealing with Resources and Stakeholders During Economic Crisis}

This question was aimed at discovering HR managers' perception of difficulty in dealing with human resources during economic crises. The findings are presented in Table 3. Six items were presented out, of which three are resources: employees, machines and money, while three are parties: investors, dealers \& suppliers, and Government. Among these options, the HR managers directly dealt with employees and with Government regarding HR issues only, and did not directly deal with machines, investors, and suppliers. Hence, their perception of difficulty in dealing with employees is understood as result of their experience, while their perception of difficulty in dealing with other resources and stakeholders is understood as a result of their comprehension of the situation. The measurement scale contained 5 points, with 1 being no problem at all to deal with and 5 being highly complicated to deal with, with an average point of 3 being moderately difficult to deal with. A high average indicates more difficult to deal with.

\begin{tabular}{lc}
\hline & $\begin{array}{c}\text { Average rating } \\
\text { (scale of 1-5) }\end{array}$ \\
\hline Difficulty of dealing with Government during crisis & 3.21 \\
\hline Difficulty of dealing with external parties during crisis & 3.06 \\
\hline Difficulty of dealing with money during crisis & 3.03 \\
\hline Difficulty of dealing with investors during crisis & 2.88 \\
\hline Difficulty of dealing with employees during crisis & 2.74 \\
\hline Difficulty of dealing with machines during crisis & 2.32 \\
\hline
\end{tabular}

Table 3. HR Managers' Perception of Difficulty in Dealing with Various Resources and Stakeholders During a Crisis

According to the respondents, dealing with Government during a crisis is more difficult. An interesting finding is that the HR managers think that dealing with employees is easier during crisis compared to dealing with other resources and other parties (Table 3). Possible reasons could be that the employees become vulnerable due to the 'fear factor'.

Probable reasons for difficulty in dealing with external parties might be due to the change of communication and change of contract terms during crises. A reason for difficulty in dealing with money could be need for saving and cost cutting.

Data presented in Table 1 presents the HR managers' perception of impact of economic crisis on the organization from the general perspective, while the finding presented in Table 4 presents their perception of the effect of economic crisis on the organization from the HR perspective.

A higher average represents the perception of a greater impact on company's HR. An average of 3.42 indicates moderate to high impact of the current economic crisis on employees' jobs and their work life. 


\begin{tabular}{lccc}
\hline & $\begin{array}{c}\text { Points on } \\
\text { scale }\end{array}$ & Frequency & Percent \\
\hline Unaffected & 1 & 9 & 8.0 \\
\hline Little effect on the jobs \& work life of employees & 2 & 14 & 12.5 \\
\hline Moderate effect & 3 & 36 & 32.1 \\
\hline More effect & 4 & 27 & 24.1 \\
\hline Significant effect & 5 & 26 & 23.2 \\
\hline Total & & 112 & 100.0 \\
\hline Average rating of effect of current economic crisis on HR & 3.42 & \\
\hline
\end{tabular}

Table 4. HR Managers' Perception of Effect of Current Economic Crisis on HR

\section{HR Practices During the Economic Crisis}

This is one of the key findings of the current research. Respondents were asked to mention a level of implementation of the given HR strategies during a crisis on a measurement scale of 1 to 5 , with an additional option of 'non-applicable'. The scale contained, 1) no plan of doing it, 2) will think of doing it, 3) planning of doing it, 4) just started doing it and 5) already started and is in full implementation.

\begin{tabular}{|c|c|c|c|c|c|}
\hline No. & & $\mathrm{N}$ & $\begin{array}{c}\text { Not } \\
\text { applicable }\end{array}$ & $\begin{array}{l}\text { Implemen- } \\
\text { tation level } \\
\text { (scale } 1-5)\end{array}$ & $\begin{array}{l}\text { Std. } \\
\text { Dev. }\end{array}$ \\
\hline 1 & Increased knowledge management activities & 102 & 10 & 3.45 & 1.340 \\
\hline 2 & Using non-monetary motivation techniques & 104 & 8 & 3.43 & 1.453 \\
\hline 3 & Cost cutting on entertainment \& recreational activities & 108 & 4 & 3.41 & 1.582 \\
\hline 4 & Redesign jobs: Job enlargement & 106 & 6 & 3.27 & 1.515 \\
\hline 5 & Abeyance of rewards and incentives & 107 & 5 & 3.22 & 1.690 \\
\hline 6 & Cost cutting on employee training and development activities & 104 & 8 & 3.12 & 1.554 \\
\hline 7 & Increased communication with employees & 107 & 5 & 3.07 & 1.574 \\
\hline 8 & Redesign jobs: Job enrichment & 103 & 9 & 2.83 & 1.498 \\
\hline 9 & Increased dependency on outsourcing & 108 & 4 & 2.81 & 1.548 \\
\hline 10 & Appointment of crisis team & 108 & 4 & 2.73 & 1.562 \\
\hline 11 & Training employees in working during crisis & 108 & 4 & 2.69 & 1.609 \\
\hline 12 & Reducing number of employees & 107 & 5 & 2.66 & 1.590 \\
\hline 13 & Lowering income options for workers & 99 & 13 & 1.93 & 1.409 \\
\hline 14 & Sending employees on un-paid leaves & 92 & 20 & 1.89 & 1.370 \\
\hline 15 & Reducing number of working hours & 84 & 28 & 1.57 & 1.056 \\
\hline
\end{tabular}

Table 5. HR Practices Adopted During Economic Crisis Arranged According to Level of Implementation 
The findings presented in Table 5 are interesting. HR managers indicated that they have increased 'knowledge management' activities in the organization (3.45). The highest rating of this item speaks of the 'professionalism' of HR managers, as they are aware of the fact that learning organizations survive crises. The next strategy being implemented during the current economic crisis is an increased use of non-monetary motivation techniques (3.43) HR managers are aware that motivation and recognition are important during crisis to ensure productivity (O’Connor, 1987). Managers now apply non-monetary techniques to motivate their employees viz., recognition letters, motivational mailers, appreciation letters, redesigning the job titles without increase in pay, promotions without increase in pay, etc. Managers have cut costs on employee entertainment activities (implementation rating of 3.41) and not on the employee developmental activities (3.12). This data speaks of the professional approach of the managers. The budget for training and development activities is usually assumed to be greater than the entertainment budget, and the managers can save more by cutting training and development costs. However, they were cutting entertainment and recreation costs, instead of cutting training and development costs.

HR strategies during economic crisis include job enlargement (3.27), i.e., adding tasks at no additional costs as this strategy can motivate employees by making their jobs more interesting and important (Noe et al., 2011). Promotions, bonuses and other benefits were kept under abeyance or postponed (3.22) which is one of the strategies usually adopted during an economic crisis (Feng, 2018; Merhan \& Tracy, 2016). The lowest rated HR strategy in implementation is reducing the number of working hours for employees (the lowest average of 1.57). In fact, $25 \%$ of the respondents specified that this strategy is not applicable to them. Mostly presumed strategy, 'downsizing' is also rated low in implementation with an average of 2.66. Thus, this finding disproves the myth that downsizing is the first HR strategy that is implemented during a crisis. This empirical survey proves most of the commonly presumed strategies as myths. For example, some of the myths from a lay-man's perspective are that HR managers reduce the number of jobs during crisis, they cut even the training and development costs, and they force employees to go on un-paid leaves. But the current research empirically proved that, in reality, these strategies are given the least amount of importance in implementation. Thus, this research attains significance.

\section{HR Managers' Perception of Resultant Effect of their Crisis-Driven HR Strategies}

This is another key finding of the current research. The respondents (HR managers) were presented seven resultant effects of crisis-driven HR strategies and were required to rate each of them on a scale of 1 to 5 in terms of effect on their human resources according to their perception (presented in Table 6). Though the scale was uniform (5-point scale), the scale description varied according to the type of effect, which is clearly explained in individual description analyses.

\section{Effect on Motivation Level}

The perceived resultant effect of crisis-driven HR strategies on the motivation level of employees was measured on a scale of 1 to 5, starting from highly reduced motivation levels to highly increased motivation levels with a center-point of moderate effect. The average of 3.11 indicates a moderate effect of crisis-driven HR strategies on employees, according to the HR managers. As this finding is from the HR managers' perspective, it needs to be validated through studying the employee behavior. However, from the HR managers' view-point, their crisis-driven HR strategies did not demotivate their employees and the reasons could be the preparedness of the employees due to awareness of the current economic crisis. 


\begin{tabular}{lccc}
\hline & $\mathrm{N}$ & Mean & $\begin{array}{c}\text { Std. } \\
\text { Deviation }\end{array}$ \\
\hline Motivation level of employees & 112 & 3.11 & 1.269 \\
\hline Commitment level of employees & 112 & 3.05 & 1.199 \\
\hline Rumors and informal communication among employees & 112 & 3.13 & 0.988 \\
\hline Employee engagement \& involvement of employees & 112 & 3.21 & 1.086 \\
\hline Active/ Passive behavior of employees at the workplace & 111 & 3.44 & 1.076 \\
\hline Employee turnover & 112 & 3.20 & 1.184 \\
\hline Corporate image among employees & 112 & 3.15 & 1.172 \\
\hline
\end{tabular}

Table 6: HR Managers' Perception of Resultant Effect of Crisis-Driven HR Strategies

\section{Effect on Commitment Level}

The measurement scale contained 5 points starting from a highly reduced commitment level to a highly increased commitment level. The opinion was that the commitment levels of employees were reduced due to stringent measures, and cost cutting needed to be validated through research. The current research attempted to find an answer to this research question. According to HR managers, their crisis-driven HR strategies did not reduce the commitment levels of their employees, and has shown moderate effect (3.05).

\section{Rumors and Informal Communication}

The crisis-driven HR strategies might encourage informal communication and generate rumors as the employees may not openly communicate or comment on the management's decisions during a crisis (Coombs \& Holladay, 2002). According to the HR managers, there is a moderate impact on communication among employees ( 3.13 on a scale of 1 to 5 ). Though informal communication is common in any organization (Bovee \& Thill, 2011), the current research proved that the crisis-driven HR strategies have a moderate effect on informal communication among employees and create room for rumors.

\section{Active and Passive Behavior at the Workplace}

This is the highest rated item on the questionnaire, with an average of 3.44 on a scale of 1 to 5 . The measurement scale contained 1) visible passive behavior, 3) moderate active and passive behavior, and 5) visible active behavior. An average of more than 3 indicates that the employees have become active in the workplace, as they are now aware of current situation. The HR managers' have noticed active behavior in the form of actively participating in meetings, coming forward for solving problems at the workplace, etc. Moreover, a low standard deviation (1.076) indicates similarity in the responses of HR managers.

\section{Employee Turnover}

According to the HR managers. the crisis-driven HR strategies have not resulted in employee loss. The measurement scale contained 1) increased employee turnover, 3) moderate employee turnover and 5) reduced employee turnover, and the respondents were required to provide their perception of the resultant effect of their HR strategies during a crisis on employee turnover. An average of more than 3 gave a good signal, as it indicated reduced employee turnover. In this study, an average of 3.20 indicated that the crisis-driven HR strategies had, in fact, reduced employee turnover as against the common opinion or myth of increased employee turnover during a crisis (Vintisa, 2010). 


\section{Employee Engagement and Involvement of Employees}

The crisis-driven HR strategies had created an active workplace environment. According to HR managers, employees involved more in constructive activities participated more actively in meetings and contributed willingly in decision-making, which contributed to enhanced employee engagement. Employee engagement created a healthy relationship between the employee and the organization (Ellis \& Sorensen, 2007). An average of 3.21 indicated moderate to high employee engagement at the workplace which was a positive resultant effect of crisis-driven HR strategies.

\section{Corporate Image Among Employees}

The assumption of lowered corporate image among employees during a crisis (Wright, 2009) could be a myth (Hansen, 2005). The current research has empirically proved that corporate image did not suffer a decrease among employees due to stringent and difficult crisis-driven HR strategies. The respondents were required to present their perception of the resultant effect of their HR strategies taken-up during crisis on corporate image of their employees. The measurement scale contained 1) reduced corporate image among employees, 3) moderate effect on corporate image, and 5) increased corporate image. An average of more than 3 can be considered as a good indicator as it indicates an increase in corporate image among employees after crisis-driven HR strategies have been implemented. The HR managers perceived (3.15) that their employees do regard and respect their organization and that the corporate image had increased among employees.

\section{Differences in Application of HR Strategies Between Small, Medium and Large Organizations}

$\mathbf{H}_{\mathbf{o}}$ : There is no significant difference in the application of HR strategies during a crisis between small, medium, and large organizations

$\mathbf{H}_{1}$ : There is a significant difference in the application of HR strategies during crisis between small, medium, and large organizations

\begin{tabular}{|c|c|c|c|}
\hline HR strategy & $p$-value & Significance & $\begin{array}{l}\text { Conclusion } \\
\text { (Post Hoc Test) }\end{array}$ \\
\hline Increased knowledge management activities & .510 & $\begin{array}{l}\text { Not significant } \\
\mathrm{H}_{\mathrm{o}}: \text { Not rejected }\end{array}$ & $* * *$ \\
\hline Using non-monetary motivation techniques & .238 & $\begin{array}{l}\text { Not significant } \\
\mathrm{H}_{\mathrm{o}}: \text { Not rejected }\end{array}$ & $* * *$ \\
\hline $\begin{array}{l}\text { Cost cutting on entertainment \& } \\
\text { recreational activities }\end{array}$ & .038 & $\begin{array}{l}\text { Significant } \\
\mathrm{H}_{\mathrm{o}}: \text { Rejected }\end{array}$ & $\begin{array}{l}\text { Application by large organi- } \\
\text { zations is significantly high- } \\
\text { er than small and medium } \\
\text { organizations (Appendix 1) }\end{array}$ \\
\hline $\begin{array}{l}\text { Redesign jobs: Job enlargement (adding } \\
\text { tasks to a job at no additional pay) }\end{array}$ & .035 & $\begin{array}{l}\text { Significant } \\
\mathrm{H}_{\mathrm{o}} \text { : Rejected }\end{array}$ & $\begin{array}{l}\text { Application by small or- } \\
\text { ganizations is significantly } \\
\text { higher than medium orga- } \\
\text { nizations (Appendix 2) }\end{array}$ \\
\hline Abeyance of rewards and incentives & .101 & $\begin{array}{l}\text { Not significant } \\
\mathrm{H}_{\mathrm{o}}: \text { Not rejected }\end{array}$ & $* * *$ \\
\hline $\begin{array}{l}\text { Cost cutting on employee training and de- } \\
\text { velopment activities }\end{array}$ & .017 & $\begin{array}{l}\text { Significant } \\
\mathrm{H}_{\mathrm{o}}: \text { Rejected }\end{array}$ & $\begin{array}{l}\text { Application by large organi- } \\
\text { zations is significantly high- } \\
\text { er than small and medium } \\
\text { organizations (Appendix } 3 \text { ) }\end{array}$ \\
\hline
\end{tabular}




\begin{tabular}{|c|c|c|c|}
\hline Increased communication with employees & .114 & $\begin{array}{l}\text { Not significant } \\
\mathrm{H}_{\mathrm{o}}: \text { Not rejected }\end{array}$ & $* * *$ \\
\hline Redesign jobs: Job enrichment & .615 & $\begin{array}{l}\text { Not significant } \\
\mathrm{H}_{\mathrm{o}}: \text { Not rejected }\end{array}$ & $* * *$ \\
\hline Increased dependency on outsourcing & .254 & $\begin{array}{l}\text { Not significant } \\
\mathrm{H}_{\mathrm{o}}: \text { Not rejected }\end{array}$ & $* * *$ \\
\hline Appointment of crisis team & .724 & $\begin{array}{l}\text { Not significant } \\
\mathrm{H}_{\mathrm{o}}: \text { Not rejected }\end{array}$ & $* * *$ \\
\hline Training employees in working during crisis & .523 & $\begin{array}{l}\text { Not significant } \\
\mathrm{H}_{\mathrm{o}}: \text { Not rejected }\end{array}$ & $* * *$ \\
\hline Reducing number of employees & .331 & $\begin{array}{l}\text { Not significant } \\
\mathrm{H}_{\mathrm{o}}: \text { Not rejected }\end{array}$ & $* * *$ \\
\hline Lowering income options for workers & .594 & $\begin{array}{l}\text { Not significant } \\
\mathrm{H}_{\mathrm{o}}: \text { Not rejected }\end{array}$ & $* * *$ \\
\hline Sending employees on un-paid leaves & .752 & $\begin{array}{l}\text { Not significant } \\
\mathrm{H}_{\mathrm{o}}: \text { Not rejected }\end{array}$ & $* * *$ \\
\hline Reducing number of working hours & .331 & $\begin{array}{l}\text { Not significant } \\
\mathrm{H}_{\mathrm{o}}: \text { Not rejected }\end{array}$ & $* * *$ \\
\hline
\end{tabular}

Grouping Variable: Number of Employees in the Organization

Small=Below 100, Medium=101 to 500, Large=More than 500 employees

Table 7. Summary of ANOVA Test Results

The organizations in the study were divided into small (under 100 employees), medium (101 to 500 employees) and large (more than 500 employees) for the purpose of hypotheses testing and further analysis. Out of 15 crisis-driven HR strategies, only three strategies namely, cost cutting on employee recreational activities, job enlargement and cost cutting on employee training and development were found to be applied at different levels in the three categories of organizations. HR managers representing large organizations have given an average implementation rating of 4.28 (on a scale of 1 to 5) to 'cost cutting on employee entertainment \& recreational activities'. Whereas HR managers of small organizations gave an average implementation rating of 3.24 and HR managers of medium organizations gave an average implementation rating of 3.25 to the same variable. An ANOVA test was conducted to identify the difference of means between groups indicated that there is a significant difference (Table 7). Later, the Post Hoc Tests (Appendix 1) indicated that the application of this strategy by large organizations is significantly higher than small and medium organizations. The reasons could be more spending on employee recreation by larger organizations compared to small and medium-sized organizations. Moreover, it can be interpreted that small organizations may not be saving significant amount of money by cutting costs on employee recreation.

The next finding is related to redesigning jobs, more specifically, job enlargement which involves adding tasks to a job with no additional pay to the employee. The ANOVA test revealed that there is a significant difference between the implementation of this strategy by large, medium and small organizations (Table $7 \&$ Appendix 2). With an average of 3.67, job enlargement strategy is applied more by small organizations compared to medium-sized organizations. Otherwise, the difference is not 
significant compared to large organizations. The reasons could be that it is easier to redesign jobs in small organizations whereas, in large organizations with hundreds and thousands of employees, it is a difficult task. Hence, HR managers of large-sized organizations might not be showing more interest in applying job enlargement activity. The last hypothesis under this section is related to cost cutting on employee training and development. The ANOVA test revealed that large sized organizations' implementation of this strategy has been significantly higher than in small and medium sized organizations (Table 7 \& Post Hoc Tests presented in Appendix 3). It can be interpreted, that as the budget for employee training and development in large sized organizations is usually higher, they can save significant amount of money on cost cutting compared to small and medium sized organizations.

Differences in HR Managers' Perception of the Resultant Effect of their HR Strategies Between Small, Medium, and Large organizations

$\mathbf{H}_{\mathbf{o}}$ : There is no significant difference in the resultant effect of crisis-driven HR strategies between small, medium, and large organizations

$\mathbf{H}_{1}$ : There is a significant difference in resultant effect of crisis-driven HR strategies between small, medium, and large organizations

\begin{tabular}{|c|c|c|c|}
\hline Resultant effect & $p$-value & Significance & Conclusion (Post Hoc Test \\
\hline Effect on motivation level & .956 & $\begin{array}{l}\text { Not significant } \\
\mathrm{H}_{\mathrm{o}}: \text { Not rejected }\end{array}$ & $* * *$ \\
\hline Effect on commitment level & .937 & $\begin{array}{l}\text { Not significant } \\
\mathrm{H}_{\mathrm{o}}: \text { Not rejected }\end{array}$ & $* * *$ \\
\hline Rumors and informal communication & .942 & $\begin{array}{l}\text { Not significant } \\
\mathrm{H}_{\mathrm{o}}: \text { Not rejected }\end{array}$ & $* * *$ \\
\hline $\begin{array}{l}\text { Employee engagement \& involvement of } \\
\text { employees }\end{array}$ & .349 & $\begin{array}{l}\text { Not significant } \\
\mathrm{H}_{\mathrm{o}}: \text { Not rejected }\end{array}$ & $* * *$ \\
\hline Active/passive behavior at workplace & .893 & $\begin{array}{l}\text { Not significant } \\
\mathrm{H}_{\mathrm{o}}: \text { Not rejected }\end{array}$ & $* * *$ \\
\hline Employee turnover & .292 & $\begin{array}{l}\text { Not significant } \\
\mathrm{H}_{\mathrm{o}}: \text { Not rejected }\end{array}$ & $* * *$ \\
\hline Corporate image among employees & .880 & $\begin{array}{l}\text { Not significant } \\
\mathrm{H}_{\mathrm{o}}: \text { Not rejected }\end{array}$ & $* * *$ \\
\hline
\end{tabular}

\section{Grouping variable: Number of Employees in the Organization}

Small=Below 100, Medium=101 to 500, Large=More than 500 employees

Table 8. Summary of ANOVA Test Results

This analysis proves that the resultant effect does not depend upon the size of the organization (Table 8). The HR managers of small, medium and large organizations equally perceive the effect of their crisisdriven HR strategies. With reference to the motivation levels of their employees after certain changes to HR strategies, all three types of HR managers mentioned that the effect is moderate to high ranging between the average values of 3.06 to 3.15 (scale 1 to 5). Similarly, with reference to active and passive behavior at the workplace, the HR managers of all three types of organizations felt that the employees 
in their respective organizations became active players at the workplace with averages of 3.49 (small), 4.39 (medium), and 3.39 (large). Thus, it can be interpreted that the resultant effect of crisis-driven HR strategies will be same, irrespective of the manpower size of the organization.

Differences in HR Managers' Perception of Resultant Effect of their HR Strategies Between the Manufacturing and Service Sectors

$\mathbf{H}_{\mathbf{o}}$ : There is no significant difference in the resultant effect of crisis-driven HR strategies between the manufacturing and service sector organizations

$\mathbf{H}_{\mathbf{1}}$ : There is a significant difference in the resultant effect of crisis-driven HR strategies between the manufacturing and service sector organizations

\begin{tabular}{|c|c|c|c|}
\hline Resultant effect & $p$-value & Significance & Conclusion \\
\hline Effect on motivation level & .872 & $\begin{array}{l}\text { Not significant } \\
\mathrm{H}_{\mathrm{o}}: \text { Not rejected }\end{array}$ & $* * *$ \\
\hline Effect on commitment level & .985 & $\begin{array}{l}\text { Not significant } \\
\mathrm{H}_{\mathrm{o}}: \text { Not rejected }\end{array}$ & $* * *$ \\
\hline Rumors and informal communication & .002 & $\begin{array}{l}\text { Significant } \\
\mathrm{H}_{\mathrm{o}}: \text { Rejected }\end{array}$ & $\begin{array}{l}\text { Significantly higher in service } \\
\text { sector (3.16) than manufac- } \\
\text { turing sector (3.03) }\end{array}$ \\
\hline $\begin{array}{l}\text { Employee engagement \& involvement of } \\
\text { employees }\end{array}$ & .023 & $\begin{array}{l}\text { Significant } \\
\mathrm{H}_{\mathrm{o}}: \text { Rejected }\end{array}$ & $\begin{array}{l}\text { Significantly higher in service } \\
\text { sector (3.22) than manufac- } \\
\text { turing sector (3.19) }\end{array}$ \\
\hline Active/passive behavior at workplace & .908 & $\begin{array}{l}\text { Not significant } \\
\mathrm{H}_{\mathrm{o}}: \text { Not rejected }\end{array}$ & $* * *$ \\
\hline Employee turnover & .048 & $\begin{array}{c}\text { Significant } \\
\mathrm{H}_{\mathrm{o}}: \text { Rejected }\end{array}$ & $\begin{array}{l}\text { Significantly higher in service } \\
\text { sector (3.32) than manufac- } \\
\text { turing sector (2.87) }\end{array}$ \\
\hline Corporate image among employees & 0.76 & $\begin{array}{l}\text { Not significant } \\
\mathrm{H}_{\mathrm{o}}: \text { Not rejected }\end{array}$ & $* * *$ \\
\hline
\end{tabular}

Grouping Variable: Sector of the Organization - Manufacturing Sector \& Service Sector

Table 9. Summary of $t$-Test Results

Another relevant thing for this study is to understand the differences between the manufacturing and service sector organizations. Though the current crisis started with the manufacturing sector (petroleum), the service sector was also suffering equally or even more. The current survey included service sector organizations like telecommunications, airlines, construction, banking, insurance, retail, education, and health, while the manufacturing sector included petroleum, food, etc. The findings of the hypotheses testing revealed that the impact had been greater in the service sector than in the manufacturing sector (Table 9). 3 out of 7 resultant effects were found to be significantly different in the two sectors and, interestingly, the impact has been significantly higher in the service sector than in the manufacturing sector. Managers from the service sector have indicated a relatively lower job loss (3.32) than HR managers from the manufacturing sector (2.87). 


\section{Differences Between HR Managers' Perceived Difficulty in Dealing with Employees Between Small, Medium and Large Organizations}

$\mathbf{H}_{\mathbf{o}}$ : There is no significant difference between the perceived difficulty in dealing with employees during a crisis between small, medium, and large organizations

$\mathbf{H}_{1}$ : There is no significant difference between the perceived difficulty in dealing with employees during a crisis between small, medium, and large organizations

\begin{tabular}{|c|c|c|c|}
\hline Testing variable & $p$-value & Significance & Conclusion (Post Hoc Test) \\
\hline $\begin{array}{l}\text { Difficulty in dealing } \\
\text { with employees dur- } \\
\text { ing crisis }\end{array}$ & .040 & $\begin{array}{c}\text { Significant } \\
\mathrm{H}_{\mathrm{o}}: \text { Rejected }\end{array}$ & $\begin{array}{l}\text { - HR managers of small organizations perceive less } \\
\text { difficulty in dealing with employees during a crisis } \\
\text { than HR managers of medium and large organiza- } \\
\text { tions } \\
\text { - HR managers of medium organizations perceive } \\
\text { less difficulty in dealing with employees during a } \\
\text { crisis than HR managers of large organizations (Ap- } \\
\text { pendix 4). }\end{array}$ \\
\hline
\end{tabular}

Grouping Variable: Number of Employees in the Organization

Small=Below 100, Medium=101 to 500, Large=More than 500 employees

Table 10. Summary of ANOVA Test Results

The general opinion that managing smaller organizations with fewer employees is relatively easier than managing larger organizations (Noe et al., 2011; Morgan, 2015) is proved to be true through this empirical research. HR managers of smaller organizations with less than 100 employees indicated that it is easier to deal with employees during a crisis with an average of 2.54 on a scale of 1 , which indicates no problem at all in dealing with employees during a crisis and 5 being highly complicated to deal with. This average is significantly lower than perceptions of HR managers representing medium-sized organizations and larger-sized organizations. Thus, it can be interpreted that, the larger the organization in terms of number of employees, the more difficult it is in dealing with them during a crisis.

Reliability Analysis

\begin{tabular}{cc}
\hline Cronbach's Alpha & N of Items \\
\hline .871 & 38 \\
\hline
\end{tabular}

Table 11. Reliability Statistics

The reliability analysis which is expected to be as close as possible to 1, indicates that the questionnaire is valid and the data collected can be used in further analyses (Reynaldo \& Santos, 1999). Cronbach's Alpha for the current research is calculated at .871 (Table 11) for 38 items on the questionnaire. This allows the researcher to arrive at reliable outputs and valid conclusions.

\section{CONCLUSIONS AND SUGGESTIONS}

Economic crisis affects all aspects of business, forcing managers to alter their functional strategies. During a crisis, dealing with human resources is a complicated function when compared with managing other business functions. Hence, managers are advised to revise their HR practices in the current 
economic crisis. This paper addresses the vital issue of the application of crisis-driven HR strategies, as well as the resultant effect through empirical research conducted in Muscat. HR practices that are being applied now can be called as 'crisis-driven HR strategies', as they are influenced by the current economic crisis and the need to be looked at from a different perspective. As findings revealed that HR managers perceive a greater impact of the economic crisis on their respective businesses compared with other types of crises, it is recommended that they redesign their HR strategies to ensure success in the current economic crisis. The research findings disproved many myths about HR strategies adopted during economic crisis. For example, instead of emphasizing cutting cost and employee separations, the HR managers emphasized on enhancing knowledge management activities in the company as they knew that learning organizations survive during difficult times. It is recommended that they further increase their knowledge management activities and communicate the same to their employees. One of the resultant effects of crisis-driven HR strategies was that the employee engagement increased, as the employees were now more involved in constructive activities and exhibited active behavior at the workplace. This further increased corporate image among employees which was earlier a myth that crisis-driven HR strategies lowerd the corporate image.

During the current economic crisis, large organizations had cut costs on employee recreation, rather than the costs related to employee training and development. It was found that small organizations performed job enlargement tasks (by adding more tasks at no additional costs) while large organizations found it difficult to deal with their employees during a crisis (due to the large size of their work force). The survey revealed a moderate increase in communication with employees, and it is recommended that the HR should increase communication with its employees and should discuss various issues and crises with them. Furthermore, it is recommended that managers and team leaders adopt more overt and planned motivation techniques. A need to appoint crisis management teams and train employees during crisis has also been identified. To perform effectively during the current economic crisis, the HR managers, may have to equip themselves with more information and acquire more knowledge in the HR domain. While this research presented a broad overview of human resource management during the current economic crisis, it calls for further research thorough inquiry into specific aspects, such as changes in job analysis and design, changes in recruitment and selection procedures, etc. Thus, through more narrowed-down research, organizations can enhance the effectiveness of their HR strategies for the overall success of their organizations.

\section{REFERENCES}

Argenti, P. A. (2002). Crisis Communication: Lessons from 9/11. Retrieved March 15, 2018, from Harvard Business Review https://hbr.org/2002/12/crisis-communication-lessons-from-911

Augustine, N. R. (1995). Managing the crisis you tried to prevent. Harvard Business Review, 73(6), 147-158.

Barton, L. (2000). Crisis in organizations. Cincinnati, Ohio: South-Western College Publishing

Baubion, C. (2013). OECD risk management: Strategic crisis management. Paris: OECD.

Bergström, O. (2018). Changing restructuring regimes in 11 European countries during and after the financial crisis. European Journal of Industrial Relations. DOI:10.1177/0959680118770747

Bovee, C. L. \& Thill, J. V. (2011). Business Communication Essentials. Harlow: Pearson Education.

Burma, Z.A. (2014). Human Resource Management and Its Importance for Today's Organizations. International Journal of Education and Social Science, 1(2), 85-94.

Coombs, W. T., \& Holladay, S. J. (1996). Communication and Attributions in a Crisis: An Experimental Study in Crisis Communication. Journal of Public Relations Research, 8(4), 279-295.

Coombs, W.T. (2004). Structuring crisis discourse knowledge: The West Pharmaceutics case. Public Relations Review, 30, 467-474. 
Coombs, W.T. (2007). Ongoing crisis communication: Planning, managing, and responding. Los Angeles: Sage Publications.

Coombs, W.T., \& Holladay, S. J. (2002). Helping crisis managers protect reputational assets: Initial tests of the situational crisis communication theory. Management Communication Quarterly, 16, 165-186.

Cronbach, L. J. (1951). Coefficient Alpha and the Internal Structure Of Tests. Psychometrika, 16, 297-334.

Ellis C.M. \& Sorensen A. (2007). Assessing Employee Engagement: The Key To Improving Productivity. Perspectives, 15(1).

Ellis, D. (2008). Citigroup to cut more than 50,000 jobs. Retrieved March 15, 2018, from Money.Cnn.Com. http:// money.cnn.com/2008/11/17/news/companies/citigroup/

Fener, T., \& Cevik, T. (2015). Leadership in Crisis Management: Separation of Leadership and Executive Concepts. Procedia Economics and Finance, 26, 695-701.

Feng, F. Z. (2018). Dynamic Compensation under Uncertainty Shocks And Limited Commitment. Boston Meetings Paper. DOI:10.2139/ssrn.2313484

Field, A. (2012). Discovering Statistics Using IBM SPSS Statistics. London: Sage Publication.

Fink, S. (1986). Crisis Management: Planning for the Inevitable. New York: Amacom.

Focus Economics (2018). Oman Economic Outlook. Retrieved March, 6, 2018, from https://www.focus-economics. com/countries/oman

Fodor, P., \& Poor, J. (2009). The Impact of the Economic and Financial Crisis on HRM and Knowledge-Management in Hungary and Slovakia - Empirical Research 2008-2009. Acta Polytechnica Hungarica, 6(3), 69-91.

Fritz, H.M., Blount, C. D., Al Busaidi, F. B., \& Al-Harthy, A. H. M. (2010). Cyclone Gonu storm surge in Oman. Estuarine, Coastal and Shelf Science, 86(1), 102-106.

Graham, C. (2017). NHS cyber attack: Everything you need to know about 'biggest ransomware' offensive in history. Retrieved February 28, 2018, from https://www.telegraph.co.uk/news/2017/05/13/nhs-cyberattack-everything-need-know-biggest-ransomware-offensive/

Hansen, F. (2005). The Turnover Myth. Retrieved June 21, 2018, from Workforce Management https://www. workforce.com/2005/06/02/THE-TURNOVER-MYTH/

Hart, P., Rosenthal, U., \& Kouzmin, A. (1993). Crisis Decision Making: The Centralization Thesis Revisited. Administration \& Society, 25(1), 12-44.

Head, M. (2014). Global unemployment rises above 200 million. Retrieved January 21, 2018, from World Socialist Website https://www.wsws.org/en/articles/2014/01/21/jobs-j21.html

Howard, T. (2013). Human Resource's Role in Crisis Events. Retrieved March 15, 2018, from https://www.feinet. com/assets/uploads/archive/files/Human\%20Resource\%27s\%20Role\%20in\%20Crisis\%20Events_0.pdf

HRMA. (2014). The Roles of Human Resources in Organizational Crisis Management. Retrieved March 15, 2018, from https://cphrbc.ca/wp-content/uploads/2014/11/rb-organizational-crisis-management.pdf

Kirov, V.N., \& Thill, P. (2018). The Impact of Crisis and Restructuring on Employment Relations in Banking: The Cases of France, Luxembourg and Romania. European Journal of Industrial Relations, 24(3), 297-315.

Kothari, C.R. (2004). Research Methodology Methods And Techniques, 2 E, New Age International Publishers, New Delhi, pp. 20.

Luxford, C. (2008). How can HR help during an economic crisis? Retrieved March 15, 2018, from https://www. hcamag.com/hr-resources/leadership/how-can-hr-help-during-an-economic-crisis-115053.aspx

Matsuka, E. (2010). The Need for Innovative Human Resources Management Practices After Economic Crisis. Human Resources Management \& Ergonomics, 4(2), 1-15.

Mehran H., \& Tracy, J. S. (2016). Deferred Cash Compensation: Enhancing Stability in the Financial Services Industry. Economic Policy Review, Aug, 61-75.

Morgan, J. (2015). Why Smaller Teams Are Better Than Larger Ones. Retrieved March 20, 2018, from https:// www.forbes.com/sites/jacobmorgan/2015/04/15/why-smaller-teams-are-better-than-larger-ones/\#77d $62 \mathrm{e} 221 \mathrm{e} 68$ 
Muscat Daily (2017). Central Bank of Oman Annual Report Unveiled. Retreived March 20, 2018, from http:// www.muscatdaily.com/archive/business/central-bank-of-oman-annual-report-unveiled-52b1

Narayan, V., John-Stewart, G., O’Malley, G., \& Gage, G. (2018). “If I had known, I would have applied”: Poor communication, job dissatisfaction, and attrition of rural health workers in Sierra Leone. Human Resources for Health, 16(1). DOI:10.1186/s12960-018-0311-y

Noe, R. A., \& Noe, R. A. (2011). Fundamentals of human resource management. New York: McGraw-Hill Irwin.

Nulty, D. D. (2008). The adequacy of response rates to online and paper surveys: what can be done? Assessment \& Evaluation in Higher Education, 33(3), 301-314. DOI:10.1080/02602930701293231

Ochetan, C. M. T., \& Ochetan, D. A. (2012). The Influence of Economic and Financial Crisis on Human Resources Management. Procedia Economics and Finance, 3, 769-774.

O'Connor, J. R. (1987). The meaning of crisis: A theoretical introduction. Oxford: Blackwell.

Oman Observer (2018). Jobs for 80,000 Omanis in Logistics Sector by 2020. Retreived March 20, 2018, from http:// www.omanobserver.om/jobs-80000-omanis-logistics-sector-2020/

Peterson, A. (18 Dec, 2014). The Sony Pictures Hack, Explained. Retrieved February 28, 2018, from https:// www.washingtonpost.com/news/the-switch/wp/2014/12/18/the-sony-pictures-hack-explained/?utm_ term $=.392 \mathrm{c} 92 \mathrm{bb} 6 \mathrm{bd} 8$

Prouska, R., \& Psychogios, A. (2016). Do not say a word! Conceptualizing employee silence in a long-term crisis context. The International Journal Of Human Resource Management, 29(5), 885-914. DOI:10.1080/0958 5192.2016.1212913.

Reynaldo, J.A., \& Santos, A. (1999) Cronbach's Alpha: A Tool for Assessing the Reliability of Scales. Journal of Extension, 37, 1-4.

Saunders, M., Lewis, P., \& Thornhill, A. (2007). Research Methods for Business Students. Harlow: Pearson Education.

Silverthorne, S. (2018). The Dark Side of Performance Bonuses. Retrieved April 28, 2018, from HBS Working Knowledge https://hbswk.hbs.edu/item/the-dark-side-of-performance-bonuses?cid=wk-rss

Smith, S. M. \& Albaum, G. S. (2010). An Introduction to Marketing Research. Qualtrics, 123, 130, 234.

Spillan, J., \& Hough, D. M. (2003). Crisis Planning in Small Businesses: Importance, Impetus and Indifference. European Management Journal, 21(3), 398-407. DOI:10.1016/S0263-2373(03)00046-X

Straub, C., Vinkenburg, C. J., Van Kleef, M., \& Hofmans, J. (2018). Effective HR implementation: the impact of supervisor support for policy use on employee perceptions and attitudes. International Journal Of Human Resource Management, 29(22), 3115-3135. DOI: 10.1080/09585192.2018.1457555

Vardarlier, P. (2016). Strategic approach to human resources management during crisis. Procedia - Social And Behavioral Sciences, 235(24), 463-472.

Vintisa, K. (2010). The Impact of Economic Crisis on Human Resources Management of Public Sector. Human Resources Management \& Ergonomics, 6(1), 1-13.

Woods, B. (2018). Snow to melt high street sales as retailers brace for more pain. Retrieved March 1, 2018, from https://www.independent.ie/world-news/snow-to-melt-high-street-sales-as-retailers-brace-for-morepain-36658839.html

Wooten, L. P., \& James, E. H. (2008). Linking Crisis Management And Leadership Competencies: The Role Of Human Resource Development. Advances In Developing Human Resources, 20(10), 1-28. DOI:10. $1177 / 1523422308316450$

Workplace Info Writers (2006). HR's role in crisis management. Retrieved February 28, 2018, from http://workplaceinfo.com.au/hr-management/performance-management/analysis/hr-s-role-in-crisis-management\#. WRPLJ9RUBIU

Wright, C. (2009). Responding to crises: A test of the situational crisis communication theory. Graduate Thesis and Dissertations, University of South Florida. Retrieved February 2, 2018, from https://scholarcommons.usf.edu/CGI/VIEWCONTENT.CGI?ARTICLE=1090\&CONTEXT=ETD 


\section{APPENDICES}

Appendix 1

\section{DESCRIPTIVES FOR ANOVA TEST 1}

Cost cutting on employee entertainment \& recreational activities

\begin{tabular}{lccc}
\hline & $\mathrm{N}$ & Mean & $\begin{array}{c}\text { Std. } \\
\text { Dev. }\end{array}$ \\
\hline Below 100 employees (small) & 38 & 3.24 & 1.584 \\
\hline 101 to 500 employees (medium) & 53 & 3.25 & 1.628 \\
\hline More than 500 employees (large) & 18 & 4.28 & 1.179 \\
\hline Total & 109 & 3.41 & 1.582 \\
\hline
\end{tabular}

\section{ANOVA}

Cost cutting on employee entertainment \& recreational activities

\begin{tabular}{lccccc}
\hline & Sum of Squares & Df & Mean Square & F & Sig. \\
\hline Between Groups & 16.131 & 2 & 8.066 & 3.362 & .038 \\
\hline Within Groups & 254.291 & 106 & 2.399 & & \\
\hline Total & 270.422 & 108 & & & \\
\hline
\end{tabular}

Post Hoc Tests

\section{Multiple Comparisons}

Cost cutting on employee entertainment \& recreational activities LSD

\begin{tabular}{|c|c|c|c|c|c|c|}
\hline \multirow{2}{*}{$\begin{array}{l}\text { (I) Number of } \\
\text { employees }\end{array}$} & \multirow{2}{*}{$\begin{array}{l}\text { (J) Number of } \\
\text { employees }\end{array}$} & \multirow{2}{*}{$\begin{array}{c}\text { Mean Difference } \\
(\mathrm{I}-\mathrm{J})\end{array}$} & \multirow{2}{*}{$\begin{array}{l}\text { Std. } \\
\text { Error }\end{array}$} & \multirow{2}{*}{ Sig. } & \multicolumn{2}{|c|}{$\begin{array}{l}\text { 95\% Confidence } \\
\text { Interval }\end{array}$} \\
\hline & & & & & $\begin{array}{l}\text { Lower } \\
\text { Bound }\end{array}$ & $\begin{array}{l}\text { Upper } \\
\text { Bound }\end{array}$ \\
\hline \multirow{2}{*}{$\begin{array}{l}\text { Below } 100 \\
\text { employees (small) }\end{array}$} & $\begin{array}{l}101 \text { to } 500 \text { employees } \\
\text { (medium) }\end{array}$ & -.008 & .329 & .980 & -.66 & .64 \\
\hline & $\begin{array}{c}\text { More than } 500 \\
\text { employees (Large) }\end{array}$ & $-1.041^{*}$ & .443 & .021 & -1.92 & -.16 \\
\hline \multirow{2}{*}{$\begin{array}{l}101 \text { to } 500 \\
\text { employees (me- } \\
\text { dium) }\end{array}$} & $\begin{array}{l}\text { Below } 100 \text { employees } \\
\text { (small) }\end{array}$ & .008 & .329 & .980 & -.64 & .66 \\
\hline & $\begin{array}{l}\text { More than } 500 \\
\text { employees (Large) }\end{array}$ & $-1.032^{*}$ & .423 & .016 & -1.87 & -.19 \\
\hline \multirow{2}{*}{$\begin{array}{l}\text { More than } 500 \\
\text { employees (Large) }\end{array}$} & $\begin{array}{c}\text { Below } 100 \\
\text { employees (small) }\end{array}$ & $1.041^{*}$ & .443 & .021 & .16 & 1.92 \\
\hline & $\begin{array}{c}101 \text { to } 500 \\
\text { employees (medium) }\end{array}$ & $1.032^{*}$ & .423 & .016 & .19 & 1.87 \\
\hline & *. The mean di & rence is signifi & the & 5 leve & & \\
\hline
\end{tabular}




\section{DESCRIPTIVES FOR ANOVA TEST 2}

Redesign jobs: Job enlargement (adding tasks at no additional payments)

\begin{tabular}{lccccccccc}
\hline & & & & & \multicolumn{3}{c}{$\begin{array}{c}\text { 95\% Confidence } \\
\text { Interval for Mean }\end{array}$} \\
& $\mathrm{N}$ & Mean & $\begin{array}{c}\text { Std. } \\
\text { Dev. }\end{array}$ & $\begin{array}{c}\text { Std. } \\
\text { Error }\end{array}$ & $\begin{array}{c}\text { Lower } \\
\text { Bound }\end{array}$ & $\begin{array}{c}\text { Upper } \\
\text { Bound }\end{array}$ & Max \\
\hline Below 100 employees (small) & 39 & 3.67 & 1.383 & .221 & 3.22 & 4.11 & 1 & 5 \\
\hline 101 to 500 employees (medium) & 51 & 2.88 & 1.492 & .209 & 2.46 & 3.30 & 1 & 5 \\
\hline More than 500 employees (Large) & 16 & 3.56 & 1.672 & .418 & 2.67 & 4.45 & 1 & 5 \\
\hline Total & 106 & 3.27 & 1.515 & .147 & 2.98 & 3.57 & 1 & 5 \\
\hline
\end{tabular}

\section{ANOVA}

Redesign jobs: Job enlargement (adding tasks at no additional payments)

\begin{tabular}{lccccc}
\hline & Sum of Squares & Df & Mean Square & F & Sig. \\
\hline Between Groups & 15.168 & 2 & 7.584 & 3.458 & .035 \\
\hline Within Groups & 225.898 & 103 & 2.193 & & \\
\hline Total & 241.066 & 105 & & & \\
\hline
\end{tabular}

\section{Post Hoc Tests}

\section{Multiple Comparisons}

Redesign jobs: Job enlargement (adding tasks at no additional payments)LSD

\begin{tabular}{|c|c|c|c|c|c|c|}
\hline \multirow{2}{*}{$\begin{array}{l}\text { (I) Number } \\
\text { of employees }\end{array}$} & \multirow{2}{*}{$\begin{array}{l}\text { (J) Number } \\
\text { of employees }\end{array}$} & \multirow{2}{*}{$\begin{array}{c}\text { Mean } \\
\text { Difference (I-J) }\end{array}$} & \multirow{2}{*}{$\begin{array}{l}\text { Std. } \\
\text { Error }\end{array}$} & \multirow[b]{2}{*}{ Sig. } & \multicolumn{2}{|c|}{$95 \%$ Confidence Interval } \\
\hline & & & & & $\begin{array}{l}\text { Lower } \\
\text { Bound }\end{array}$ & $\begin{array}{l}\text { Upper } \\
\text { Bound }\end{array}$ \\
\hline \multirow{2}{*}{$\begin{array}{l}\text { Below } 100 \\
\text { employees (small) }\end{array}$} & $\begin{array}{l}101 \text { to } 500 \\
\text { employees (medium) }\end{array}$ & $.784^{*}$ & .315 & .014 & .16 & 1.41 \\
\hline & $\begin{array}{l}\text { More than } 500 \\
\text { employees (Large) }\end{array}$ & .104 & .440 & .813 & -.77 & .98 \\
\hline \multirow{2}{*}{$\begin{array}{l}101 \text { to } 500 \\
\text { employees } \\
\text { (medium) }\end{array}$} & $\begin{array}{c}\text { Below } 100 \\
\text { employees (small) }\end{array}$ & $-.784^{*}$ & .315 & .014 & -1.41 & -.16 \\
\hline & $\begin{array}{l}\text { More than } 500 \\
\text { employees (Large) }\end{array}$ & -.680 & .424 & .112 & -1.52 & .16 \\
\hline \multirow{2}{*}{$\begin{array}{l}\text { More than } 500 \\
\text { employees (Large) }\end{array}$} & $\begin{array}{c}\text { Below } 100 \\
\text { employees (small) }\end{array}$ & -.104 & .440 & .813 & -.98 & .77 \\
\hline & $\begin{array}{c}101 \text { to } 500 \\
\text { employees (medium) }\end{array}$ & .680 & .424 & .112 & -.16 & 1.52 \\
\hline
\end{tabular}




\section{Appendix 3}

\section{DESCRIPTIVES FOR ANOVA TEST 3}

Cost cutting on employee training and development activities

\begin{tabular}{|c|c|c|c|c|c|c|c|c|}
\hline & \multirow{2}{*}{$\mathrm{N}$} & \multirow{2}{*}{ Mean } & \multirow{2}{*}{$\begin{array}{l}\text { Std. } \\
\text { Dev. }\end{array}$} & \multirow{2}{*}{$\begin{array}{l}\text { Std. } \\
\text { Error }\end{array}$} & \multicolumn{2}{|c|}{$\begin{array}{l}\text { 95\% Confidence } \\
\text { Interval for Mean }\end{array}$} & \multirow{2}{*}{ Min } & \multirow{2}{*}{$\operatorname{Max}$} \\
\hline & & & & & $\begin{array}{l}\text { Lower } \\
\text { Bound }\end{array}$ & $\begin{array}{l}\text { Upper } \\
\text { Bound }\end{array}$ & & \\
\hline Below 100 employees (small) & 38 & 3.13 & 1.455 & .236 & 2.65 & 3.61 & 1 & 5 \\
\hline 101 to 500 employees (medium) & 50 & 2.80 & 1.565 & .221 & 2.36 & 3.24 & 1 & 5 \\
\hline More than 500 employees (Large) & 16 & 4.06 & 1.436 & .359 & 3.30 & 4.83 & 1 & 5 \\
\hline Total & 104 & 3.12 & 1.554 & .152 & 2.81 & 3.42 & 1 & 5 \\
\hline
\end{tabular}

\section{ANOVA}

Cost cutting on employee training and development activities

\begin{tabular}{lccccc}
\hline & Sum of Squares & df & Mean Square & F & Sig. \\
\hline Between Groups & 19.336 & 2 & 9.668 & 4.259 & .017 \\
\hline Within Groups & 229.280 & 101 & 2.270 & & \\
\hline Total & 248.615 & 103 & & & \\
\hline
\end{tabular}

Post Hoc Tests

\section{Multiple Comparisons}

Cost cutting on employee training and development activities LSD

(I) Number of employees
(J) Number of employees
Mean

Difference (I-J)
95\% Confidence Interval

Std. Error
Sig.

\begin{tabular}{|c|c|c|c|c|c|c|}
\hline \multirow{2}{*}{$\begin{array}{l}\text { Below } 100 \\
\text { employees (small) }\end{array}$} & $\begin{array}{c}101 \text { to } 500 \\
\text { mployees (medium) }\end{array}$ & .332 & .324 & .309 & -.31 & .97 \\
\hline & $\begin{array}{l}\text { More than } 500 \\
\text { employees (Large) }\end{array}$ & $-.931^{*}$ & .449 & .041 & -1.82 & -.04 \\
\hline \multirow{2}{*}{$\begin{array}{l}101 \text { to } 500 \\
\text { employees (medium) }\end{array}$} & $\begin{array}{c}\text { Below } 100 \\
\text { employees (small) }\end{array}$ & -.332 & .324 & .309 & -.97 & .31 \\
\hline & $\begin{array}{l}\text { More than } 500 \\
\text { employees (Large) }\end{array}$ & $-1.263^{*}$ & .433 & .004 & -2.12 & -.40 \\
\hline \multirow{2}{*}{$\begin{array}{l}\text { More than } 500 \\
\text { employees (Large) }\end{array}$} & $\begin{array}{c}\text { Below } 100 \\
\text { employees (small) }\end{array}$ & $.931^{*}$ & .449 & .041 & .04 & 1.82 \\
\hline & $\begin{array}{l}101 \text { to } 500 \text { employees } \\
\text { (medium) }\end{array}$ & $1.263^{*}$ & .433 & .004 & .40 & 2.12 \\
\hline
\end{tabular}




\section{DESCRIPTIVES FOR ANOVA TEST 4}

Difficulty of dealing with employees during crisis

\begin{tabular}{|c|c|c|c|c|c|c|c|c|}
\hline & \multirow{2}{*}{$\mathrm{N}$} & \multirow{2}{*}{ Mean } & \multirow{2}{*}{$\begin{array}{l}\text { Std. } \\
\text { Dev. }\end{array}$} & \multirow{2}{*}{$\begin{array}{l}\text { Std. } \\
\text { Error }\end{array}$} & \multicolumn{2}{|c|}{$\begin{array}{l}\text { 95\% Confidence } \\
\text { Interval for Mean }\end{array}$} & \multirow{2}{*}{ Min } & \multirow{2}{*}{$\operatorname{Max}$} \\
\hline & & & & & $\begin{array}{l}\text { Lower } \\
\text { Bound }\end{array}$ & $\begin{array}{l}\text { Upper } \\
\text { Bound }\end{array}$ & & \\
\hline Below 100 employees (small) & 39 & 2.54 & 1.144 & .183 & 2.17 & 2.91 & 1 & 5 \\
\hline 101 to 500 employees (medium) & 55 & 2.71 & .916 & .124 & 2.46 & 2.96 & 1 & 5 \\
\hline More than 500 employees (Large) & 18 & 3.28 & 1.018 & .240 & 2.77 & 3.78 & 2 & 5 \\
\hline Total & 112 & 2.74 & 1.038 & .098 & 2.55 & 2.94 & 1 & 5 \\
\hline
\end{tabular}

\section{ANOVA}

Difficulty of dealing with employees during crisis

\begin{tabular}{lccccc}
\hline & Sum of Squares & df & Mean Square & F & Sig. \\
\hline Between Groups & 6.842 & 2 & 3.421 & 3.310 & .040 \\
\hline Within Groups & 112.649 & 109 & 1.033 & & \\
\hline Total & 119.491 & 111 & & & \\
\hline
\end{tabular}

\section{Post Hoc Tests}

\section{Multiple Comparisons}

Difficulty of dealing with employees during crisis LSD

(I) Number of employees (J) Number of
employees
Mean Difference (I-J)
95\% Confidence

Interval

Std. Error Sig.

Lower Upper

Bound Bound

\begin{tabular}{|c|c|c|c|c|c|c|}
\hline \multirow{2}{*}{$\begin{array}{l}\text { Below } 100 \\
\text { employees (small) }\end{array}$} & $\begin{array}{c}101 \text { to } 500 \\
\text { employees (medium) }\end{array}$ & -.171 & .213 & .424 & -.59 & .25 \\
\hline & $\begin{array}{l}\text { More than } 500 \\
\text { employees (Large) }\end{array}$ & $-.739^{*}$ & .290 & .012 & -1.31 & -.17 \\
\hline \multirow{2}{*}{$\begin{array}{l}101 \text { to } 500 \\
\text { employees (medium) }\end{array}$} & $\begin{array}{c}\text { Below } 100 \\
\text { employees (small) }\end{array}$ & .171 & .213 & .424 & -.25 & .59 \\
\hline & $\begin{array}{l}\text { More than } 500 \\
\text { employees (Large) }\end{array}$ & $-.569^{*}$ & .276 & .042 & -1.12 & -.02 \\
\hline \multirow{2}{*}{$\begin{array}{l}\text { More than } 500 \\
\text { employees (Large) }\end{array}$} & $\begin{array}{l}\text { Below } 100 \\
\text { employees (small) }\end{array}$ & $.739^{*}$ & .290 & .012 & .17 & 1.31 \\
\hline & $\begin{array}{c}101 \text { to } 500 \\
\text { employees (medium) }\end{array}$ & $.569^{*}$ & .276 & .042 & .02 & 1.12 \\
\hline
\end{tabular}




\section{EFEKTI KRIZNIH HR STRATEGIJA PRIMENJENIH ZA VREME TRENUTNE EKONOMSKE KRIZE U OMANU - STANOVIŠTE JEDNOG HR MENADŽERA}

\section{Rezime:}

Tokom ekonomske krize, kompanije nastoje da preoblikuju svoj način rada, a sa ciljem opstanka i napretka. Ovaj rad teži da osvetli praksu iz okvira ljudskih resursa koja je primenjena za vreme trenutne ekonomske krize u Omanu, istovremeno ilustrujući efekte kriznih strategija, iz ugla jednog menažera za ljudske resurse. Osnovni podaci dobijeni su posredstvom interneta, od strane 112 HR menadžera, iz različitih organizacija koje se bave proizvodnjom i uslugama u Muskatu, Oman. Utvrđeno je da HR menadžeri ekonomsku krizu doživljavaju kao činioca koji ostavlja značajnije efekte na njihovo poslovanje od efekata krize druge prirode, kao što su prirodna ili tehnološka. Oni veruju da je, tokom kriznog perioda, relativno jednostavnije upravljati zaposlenima nego drugim izvorima i ostalim zainteresovanim stranama. Izmene u HR praksi tokom perioda ekonomske krize uključuju ukidanje povlastica namenjenih zaposlenima, kao i smanjenje troškova u vezi sa njihovim rekreativnim aktivnostima. Umesto toga, krizni HR menadžment dovodi do umnožavanja aktivnosti u vezi sa menadžmentom znanja, ali i usvajanja tehnika motivacije koja ne uključuje novčana sredstva. Kao rezultat, primećeno je značajnije učešće zaposlenih u aktivnostima, te unapređena korporativna slika među njima. Proveravanje polazne hipoteze dovelo je do zaključka da je smanjivanje troškova, a u vezi sa rekreativnim aktivnostima zaposlenih, značajno više u velikim organizacijama, da je preoblikovanje aktivnosti značajno više u manjim organizacijama, ali i da velike organizacije imaju poteškoće u odnosu i radu sa zaposlenima tokom perioda krize, u većoj meri u odnosu na male i organizacije srednje veličine.
Ključne reči:

ekonomska kriza, ukidanje, preoblikovanje aktivnosti, ne-novčana motivacija, menadžment znanja 